\title{
Carcass and beef quality of crossbred cattle fed increasing linseed oil levels
}

\section{Qualidade da carcaça e da carne de bovinos mestiços alimentados com níveis crescentes de óleo de linhaça}

\author{
Bruna Laurindo Rosa ${ }^{1 *}$; Emanuel Almeida de Oliveira²; Wignez Henrique ${ }^{3}$; Thiago \\ Martins Pivaro4; Diego Azevedo Mota5; Cassio Toledo Messias ${ }^{1}$; Patrícia Gelli \\ Feres de Marchi' ${ }^{1}$, Lidianne Assis Silva ${ }^{1}$; Danielle Saldanha de Souza Araújo ${ }^{6}$
}

\section{Highlights}

Beef quality is improved by increasing PUFA with addition of linseed oil.

Steers and heifers produce quality meat.

Increased linseed oil levels decreased dry matter intake, increasing feed efficiency.

\section{Abstract}

Strategies to improve beef nutritional value, mainly fatty acid composition, have been a major goal for the scientific community. The use of different oil contents, mostly those rich in unsaturated fatty acids, can be interesting for cost reduction, as well as cattle performance and meat quality improvements. This study assessed the influence of diets containing increasing linseed oil levels (1.0, 3.8, and 5.2\% DM) on performance, carcass traits, and meat quality of feedlot-finished Nellore $x$ Canchim steers and heifers. The experiment was carried out in a randomized block design and arranged in a mixed $3 \times 2$ factorial scheme. Increasing oil levels linearly decreased dry matter intake (DMI) $(P<0.05)$ and hence improved feed efficiency $(P<0.05)$, regardless of sexual condition. A beneficial effect of increasing the inclusion of linseed oil was the reduction DMI. Steers had a higher weight at slaughter $(P<0.05)$ and heifers had greater backfat thickness $(P<0.05)$. The concentrations of most fatty acids were changed by the linseed oil levels studied $(P<0.05)$. Dietary inclusion of linseed oil improved beef quality by reducing $(P<0.05)$ the $n-6: n-3$ ratio by 1.3 points per percentage point increase in linseed oil level in the finishing diet of both sexes.

Key words: Beef cattle. Crossbred. Fatty acids. Finishing. Loin.

1 Profs. Drs., Universidade Federal do Acre, UFAC, Rio Branco, AC, Brazil. E-mail: bruna.rosa@ufac.br; cassio.messias@ ufac.br; patrícia.marchi@ufac.br; lidianne.silva@ufac.br

2 Zootechnist and Researcher, De Heus Nutrição Animal, Rio Claro, SP, Brazil. E-mail: emanuel.zootec@gmail.com

${ }^{3}$ Researcher, Agência Paulista de Tecnologia dos Agronegócios, APTA, São José do Rio Preto, SP, Brazil. E-mail: wignez@terra.com.br

${ }^{4}$ Zootechnist and Researcher, Cargill/Nutron, Cuiabá, MT, Brazil. E-mail: thiago_pivaro@cargill.com

${ }^{5}$ Prof. Dr., Universidade Federal dos Vales do Jequitinhonha e Mucuri, ICA/UFVJM, Unaí, MG, Brazil. E-mail: diego. mota@ufvjm.edu.br

${ }^{6}$ M.e. Student in the Programa de Pós-Graduação em Sanidade e Produção Animal Sustentável na Amazônia Ocidental, PPGESPA, UFAC, Rio Branco, AC, Brazil. E-mail: dani-saldanha@live.com

* Author for correspondence

Received: Mar. 02, 2021 - Approved: Aug. 19, 2021 


\section{Resumo}

Estratégias para melhorar os aspectos nutricionais da carne bovina, principalmente sua composição em ácidos graxos, têm se tornado uma meta importante para a comunidade científica. O uso de diferentes níveis de óleo, rico em ácidos graxos insaturados, pode ser uma estratégia interessante para redução de custos com melhoria no desempenho e na qualidade da carne. Este estudo avaliou a influência de dietas contendo níveis crescentes de óleo de linhaça (1,0; 3,8 e 5,2\% MS) no desempenho, características de carcaça e qualidade da carne de novilhos e novilhas Nelore $x$ Canchim terminados em confinamento. $\mathrm{O}$ delineamento foi em blocos casualizados em esquema fatorial $3 \times 2$ em modelo misto. Um aumento nos níveis de óleo diminuiu linearmente o consumo de matéria seca (CMS) $(P<0,05)$ e, consequentemente, melhorou a eficiência alimentar $(P<0,05)$, independentemente da condição sexual. Um efeito benéfico do aumento da inclusão do óleo de linhaça foi a redução no CMS. Os novilhos apresentaram maior peso ao abate $(P<0,05)$ e as novilhas apresentaram maior espessura de toucinho $(P<0,05)$. $A$ concentração da maioria dos ácidos graxos foi alterada pelos níveis de óleo de linhaça $(P<0,05)$. A inclusão de óleo de linhaça melhora a qualidade da carne ao reduzir $(P<0,05)$ a razão $n-6$ : $n-3$ em 1,3 pontos para cada aumento de ponto percentual de óleo de linhaça na dieta de terminação de ambos os sexos.

Palavras-chave: Ácidos graxos. Bovinos de corte. Lombo. Mestiços. Terminação.

\section{Introduction}

Especially in ruminant species, high levels of saturated fatty acids relative to polyunsaturated fatty acids (PUFA) PUFA n-6 to $n-3$, have been criticized based mostly on cardiovascular health. This has encouraged animal and meat scientists to search for an alternative to change meat fatty acid composition using different feed ingredients (Wood, 2017). Moreover, saturated fat consumption has been associated with an increased risk of obesity, cardiovascular diseases, and cancer (Vahmani et al., 2020). In this regard, small amounts have been recommended (Vargas-Bello-Pérez \& Larraín, 2017), and accordingly fostering studies to improve beef lipid composition. To do so, cattle diet supplementation with vegetable oils is an interesting strategy that has been investigated in several studies (Gema \& Gaspar, 2012; Oliveira et al., 2012).
Finishing diets can change beef lipid composition. Nassu et al. (2011) stated that greater amounts of grains increase $n-6$ fatty acid contents, while grass and foragebased diets raise n-3 fatty acid amounts. However, studies on the effect of different oil amounts, particularly linseed, are scarce or have been conducted in animal species other than cattle. According to Cupersmid, Fraga, Abreu and Pereira (2012), linseed oil is low in saturated fatty acids $(9.0 \%)$, and more than half of its unsaturated fatty acids belong to the $\mathrm{n}-3$ family. This type of fatty acid exerts important immune functions, reducing inflammation and the risk of cardiovascular diseases in humans (Kalupahana, Claycombe, \& Moustaid-Moussa, 2011). Large amounts of lipids in ruminant diets ( $>7.0 \%$ dry matter, DM) may reduce animal performance because of unsaturated fatty acid toxic effect on ruminal microorganisms (Abuelfatah, Zuki, Goh, Sazili, \& Abubakr, 2016). Therefore, one should find 
the minimum amount of lipids to be added into cattle diets to improve meat quality, without increasing costs or promoting adverse effects on animals.

Meat quality factors, such as fatty acid composition and tenderness, can be affected by sexual conditions due to differences in animal metabolism. The sexual condition also influences the carcass and sensory traits of beef cattle. In this respect, heifers and steers are interesting alternatives to produce wellfinished carcasses (Blanco, Ripoll, Delavaud, \& Casasús, 2020). This study aimed to evaluate the performance, carcass traits, and meat quality of Nellore $x$ Canchim steers and heifers fed diets with increasing linseed oil levels by measuring reductions in meat $n-6: n-3$ ratio.

\section{Materials and Methods}

The experimental procedures were approved by the Institutional Animal Care and Use Committee of the São Paulo State University (UNESP) (IACUC, \#20.541/10). The experiment was conducted at the College of Agricultural and Veterinarian Sciences (FCAV), UNESP, Campus of Jaboticabal - SP (Brazil). To this end, 15 Nellore $x$ Canchim steers and 14 Nellore $x$ Canchim heifers aged $24 \pm 2$ months were used. All animals came from the same herd and had been sired by the same bull. Steers were castrated at 15 months of age. The animals were housed in individual, covered, and concreted pens, to where they were adapted for $28 \mathrm{~d}$. During this period, the diet consisted of sugarcane and concentrate (soybean meal, corn, and mineral core), with roughage initially accounting for $60 \%$ of the dietary DM, which was decreased by $10 \%$ every week. Three isonitrogenous diets were formulated (Table 1.) using the $\mathrm{RLM}^{\circledR}$ program (ESALQ/USP, Piracicaba, São Paulo, Brazil) and added with increasing levels of commercial fresh unrefined linseed oil $(1.0,3.8$, and $5.2 \%$, on a DM basis).

\section{Table 1}

Nutritional, chemical, and fatty acid compositions of the experimental diets.

\begin{tabular}{lccc} 
& \multicolumn{2}{c}{ Linseed oil level (\% DM) } \\
\cline { 2 - 4 } & Ingredient & 3.8 & 5.2 \\
Diet composition (\% DM) & 1.0 & 20.0 & 20.0 \\
Sugar cane & 20.0 & 47.0 & 44.0 \\
Cracked corn & 50.0 & 3.0 & 2.2 \\
Soybean meal & 2.0 & 22.2 & 24.6 \\
Corn gluten meal & 23.0 & 1.0 & 1.0 \\
Urea & 1.0 & 3.8 & 5.2 \\
Linseed oil & 1.0 & 2.0 & 2.0 \\
Mineral mixture & & 0.4 & 0.4 \\
Magnesium oxide & 2.0 & 0.4 & 0.6 \\
Sodium bicarbonate & 0.4 & 0.6 &
\end{tabular}


continuation...

\begin{tabular}{|c|c|c|c|}
\hline \multicolumn{4}{|l|}{ Nutritional characteristics } \\
\hline DM (\%) & 76.27 & 76.29 & 75.65 \\
\hline CP (\% DM) & 13.77 & 14.87 & 14.03 \\
\hline $\mathrm{EE}^{2}(\% \mathrm{DM})$ & 4.68 & 6.99 & 7.86 \\
\hline NDF (\% DM) & 33.63 & 31.38 & 33.11 \\
\hline $\mathrm{TDN}^{3}$ (\% DM) & 77.12 & 80.65 & 81.96 \\
\hline \multicolumn{4}{|c|}{ Fatty acid composition (\% total fatty acids) } \\
\hline Capric (C10:0) & 0.24 & 0.24 & 0.24 \\
\hline Lauric (C12:0) & 0.30 & 0.29 & 0.29 \\
\hline Myristic (C14:0) & 0.32 & 0.34 & 0.34 \\
\hline Pentadecanoic (C15:0) & 0.11 & 0.12 & 0.11 \\
\hline Palmitic (C16:0) & 19.98 & 19.76 & 20.17 \\
\hline Palmitoleic (C16:1 cis 9) & 0.25 & 0.26 & 0.26 \\
\hline Heptadecanoic (C17:0) & 0.20 & 0.21 & 0.21 \\
\hline Heptadecenoic (C17:1 cis10) & 0.07 & 0.07 & 0.07 \\
\hline Stearic (C18:0) & 3.71 & 3.75 & 3.95 \\
\hline Oleic (C18:1 cis 9 n-9) & 33.37 & 32.72 & 34.04 \\
\hline Vaccenic (C18:1 cis $11 n-7)$ & 0.88 & 0.90 & 0.87 \\
\hline Linoleic (C18:2 cis 9,12 n-6) & 33.95 & 35.00 & 30.77 \\
\hline$\alpha$-Linolenic (C18:3 cis 9,12,15 n-3) & 4.19 & 3.91 & 6.22 \\
\hline y-Linolenic (C18:3 cis 6,9,12 n-6) & 0.05 & 0.05 & 0.04 \\
\hline Arachidic (C20:0) & 0.94 & 0.93 & 0.94 \\
\hline Eicosenoic (C20:1 cis $11 \mathrm{n}-9$ ) & 0.32 & 0.31 & 0.33 \\
\hline Behenic (C22:0) & 0.44 & 0.45 & 0.45 \\
\hline Tricosanoic (C23:0) & 0.11 & 0.12 & 0.12 \\
\hline Lignoceric (C24:0) & 0.57 & 0.57 & 0.58 \\
\hline
\end{tabular}

${ }^{1}$ Composition per kg product: phosphorus $=40 \mathrm{~g} ;$ calcium $=146 \mathrm{~g} ;$ sodium $=56 \mathrm{~g} ;$ sulfur $=40 \mathrm{~g} ;$ magnesium $=20 \mathrm{~g}$; copper $=350 \mathrm{~g} ;$ zinc $=1,300 \mathrm{mg}$; manganese $=900 \mathrm{mg} ;$ iron = 1,050 mg; cobalt $=10 \mathrm{mg} ;$ iodine $=24 \mathrm{mg} ;$ selenium = $10 \mathrm{mg}$; fluorine $=400 \mathrm{mg}$. ${ }^{2} \mathrm{EE}$ : Ether extract; ${ }^{3} \mathrm{TDN}$ : Total digestible nutrients; Value estimated using the RLM ${ }^{\circledR}$ software (ESALQ/USP).

The amount of $3.8 \%$ linseed oil had already been tested before in beef finishing diets and was shown to be beneficial for meat quality (Oliveira et al., 2012). Moreover, the level of $5.2 \%$ was the maximum recommended by the program used in this study. As roughage, sugarcane plants of the variety IAC 86-2480, harvested and chopped daily, were exclusively used. Two daily meals were provided at 8:00 and 15:00 $\mathrm{h}$ in form of complete feed, with oil added daily. The amount of food offered resulted in leftovers of about $12 \%$ of the amount consumed the day before. Both food and leftovers were sampled weekly and analyzed for DM and ether extract using the Association of Official Analytical Chemists (AOAC) method (Association of Official Analytical Chemists [AOAC], 1995). The animals were weighed at 
the beginning and end of the experiment after complete fasting for $15 \mathrm{~h}$. The animals were slaughtered when reached a body weight (BW) of $500 \mathrm{~kg}$. Thus, two animal blocks were slaughtered after 96 days in confinement, two after 110 days, and one after 138 days. All animals were slaughtered in a commercial facility and according to São Paulo State standard procedures.

After cooling for $24 \mathrm{~h}$, Longissimus thoracis muscle (LM) samples were removed from the left half-carcasses, and backfat thickness was measured with a digital caliper between the $12^{\text {th }}$ and $13^{\text {th }}$ ribs. Steaks were cut $(2.54 \mathrm{~cm}$ thick) and used to assess $\mathrm{pH}$ with a digital $\mathrm{pH}$ meter (Testo 230, Testo $\mathrm{GmbH}$ \& Co., Germany), water holding capacity (Hamm, 1986), and meat color (Houben, Van Dijk, Eikelenboom, \& Hoving-Bolink, 2000) with a portable colorimeter (EZ Miniscan, HunterLab, USA). Meat color was assessed by removing the top layer of steaks at different locations to expose myoglobin to oxygen, 30 minutes before the procedure (Abularach, Rocha, \& Felício, 1998; Oliveira et al., 2012). Total collagen (AOAC, 2005) and cholesterol (Saldanha, Mazalli, \& Bragagnolo, 2004) were also analyzed.

Cooking losses were measured on other steak samples, which were roasted in an electric oven set at $175^{\circ} \mathrm{C}$. The steak was removed from the oven when its geometric center reached $71^{\circ} \mathrm{C}$. Cooking losses were calculated by weighing steaks before and after cooking. After $24 \mathrm{~h}$ cooling in a biochemical oxygen demand (BOD) chamber, six 1.27-cmwide cylinders were removed from each steak to determine transverse cutting strength, using a texture analyzer (Texture Analyzer CT325K, Brookfield, USA) coupled to a Warner-Bratzler blade (Wheeler et al., 2002). The shear force of each steak comprised the average of the six cylinders.

Meat chemical and fatty acid composition were assessed in samples freeze-dried and ground with liquid nitrogen. Moisture, ether extract, protein, and mineral contents were analyzed (AOAC, 1995). The fatty acid composition was evaluated by extraction of fatty matter with a mixture of chloroform: methanol: water (1.0:2.0:0.8), using the method described by Bligh and Dyer (1959), while fatty acids methyl esters (FAME) were obtained by ISO 5509 method (1978). Fatty acids were analyzed qualitatively by gas chromatography, as described by Oliveira et al. (2012). The concentration of each fatty acid was calculated and divided into classes. They were also classified by functionality as hypocholesterolemic, hypercholesterolemic, neutrals, and residuals, according to Bessa, Lourenço, Portugal and Santos-Silva (2008), Oliveira et al. (2017). Thrombogenicity and atherogenicity indices were determined as in Ulbricht and Southage (1991). The activities of elongase and $\Delta^{9}$ desaturases (C16 and C18) were calculated as described by Malau-Aduli, Siebert, Bottema and Pitchford (1998).

The Shapiro-Wilk test was used to verify whether data showed a normal distribution of variances $(P<0.05)$ and, if needed, the data were transformed (SAS Institute, Inc., Cary, NC). The experimental design consisted of incomplete randomized blocks, which were divided according to initial BW into a $3 \times 2$ factorial scheme (oil level and sexual condition), totaling 29 experimental units. The analytical model included the initial weight as a covariate and blocks as random effects. The mixed procedure of the SAS software (SAS Institute, Inc., Cary, NC) was used for analysis. Oil levels were evaluated by 
(Table 3.). Other meat physical and chemical properties, such as $\mathrm{pH}$, color, water holding capacity, cooking losses, moisture, ether extract, protein, collagen, and cholesterol were not affected $(P>0.05)$ by linseed oil levels or sexual condition (Table 2.).

Except for arachidonic acid (C20:4 cis $5,8,11,14 \mathrm{n6}$ ), docosahexaenoic acid (DHA; C22:6 cis $4,7,10,13,16,19 \mathrm{n} 3)$ and nervonic acid (C24:1 cis 15 n9) (Table 3.), interactions between oil levels and sexual condition did not affect LM composition ( $P>0.05$ ) (Table 4).

Higher linseed oil levels added to the diet linearly decreased $(P<0.05)$ levels of eicosadienoic (C20:2 cis-11,14), eicosatrienoic (C20:3 n-3 cis 11,14,17), and docosatetraenoic (DTA; C22:4 n-6 cis$7,0,13,16)$ acids; linearly increased $(P<0.05)$ levels of conjugated linoleic acid (CLA; C18:2 cis 9, trans-11), $\alpha$-linolenic acid (C18:3 cis 9,12,15 n-3), and eicosapentaenoic acid (EPA; C20:5 cis $5,8,11,14,17 n-3) ;$ and quadratically increased $(P<0.05)$ level of $y$-linolenic acid (C18:3 n-6) (Table 4). Other fatty acids were not affected by increasing linseed oil levels added to the finishing diet of cattle $(P>0.05)$ (Table 4.). No difference in fatty acid composition was observed between steers and heifers $(P>0.05)$ (Table 4.). The interaction evaluation showed that steers and heifers exhibited different levels of C20:4 n6, C22:6 n-3, and C24:1 n-9 in meat only when they received $1.0 \%$ linseed oil in the diet $(P<0.05)$, while no difference was observed for the other acids (Table 3.). Meat levels of $\mathrm{C} 22: 6 \mathrm{n}-3$ reduced in heifers receiving the highest proportion of linseed oil $(P<0.05)$, while an increase in C24:1 n-9 concentration was observed in steers $(P<0.05)$. 


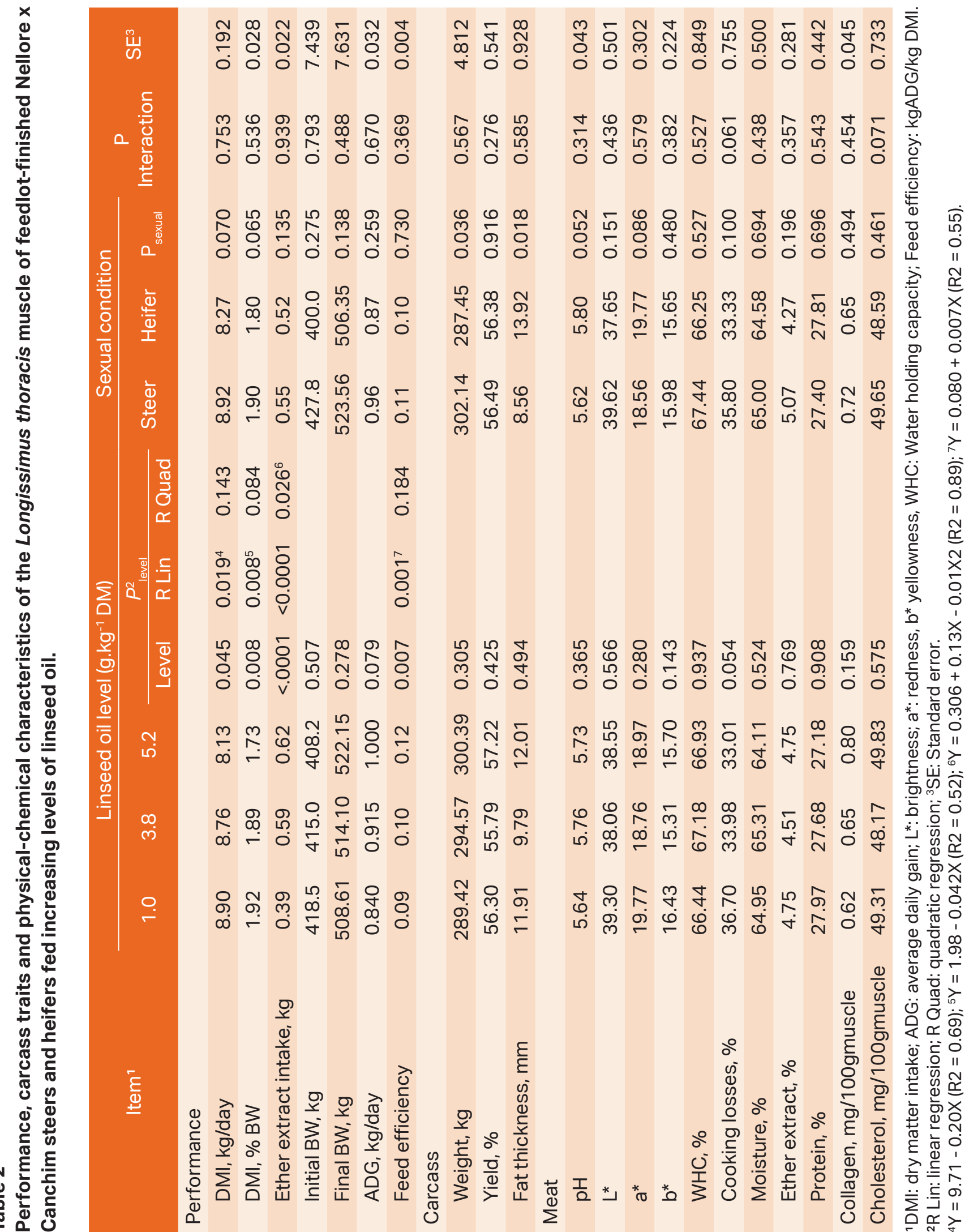




\section{Table 3}

Effect of the interaction between linseed oil level and sexual condition on shear force (kg), mineral content (\%), C20:4 n6, C22:6 n3 and C24:1 n9 fatty acids (mg/100g meat) and activity of $\Delta^{9}$ desaturase C16 in Longissimus thoracis muscle of feedlot-finished Nellore $x$ Canchim steers and heifers fed increasing levels of linseed oil.

\begin{tabular}{|c|c|c|c|c|c|c|}
\hline \multirow{2}{*}{ Sexual condition } & \multicolumn{3}{|c|}{ Linseed oil level (g.kg-1 DM) } & \multicolumn{3}{|c|}{$P^{3}$} \\
\hline & 1.0 & 3.8 & 5.2 & Level & $\mathrm{R} \operatorname{Lin}^{1}$ & R Quad $^{1}$ \\
\hline \multicolumn{7}{|c|}{ Shear Force $(\mathrm{kg})\left(P\right.$ interaction $\left.=0.020 ; \mathrm{SE}^{2}=0.16\right)$} \\
\hline Steer & 4.48 & 4.57 & 4.75 & 0.327 & & \\
\hline Heifers & 6.05 & 5.68 & 4.92 & 0.041 & 0.0444 & 0.333 \\
\hline Prob $^{1}$ & 0.012 & 0.051 & 0.748 & & & \\
\hline \multicolumn{7}{|c|}{ Mineral $(\%)\left(P\right.$ interaction $\left.=0.016 ; \mathrm{SE}^{2}=0.02\right)$} \\
\hline Steer & 1.45 & 1.45 & 1.51 & 0.836 & & \\
\hline Heifers & 1.60 & 1.48 & 1.32 & 0.038 & 0.0225 & 0.482 \\
\hline Prob $^{1}$ & 0.581 & 0.999 & 0.275 & & & \\
\hline \multicolumn{7}{|c|}{$\mathrm{C} 20: 4$ cis $5,8,11,14 \mathrm{n}-6\left(P\right.$ interaction $\left.=0.009 ; \mathrm{SE}^{2}=0.001\right)$} \\
\hline Steer & 0.024 & 0.031 & 0.032 & 0.141 & & \\
\hline Heifers & 0.040 & 0.038 & 0.027 & 0.122 & & \\
\hline Prob $^{1}$ & 0.008 & 0.154 & 0.423 & & & \\
\hline \multicolumn{7}{|c|}{$\mathrm{C} 22: 6$ cis $4,7,10,13,16,19 \mathrm{n}-3\left(P\right.$ interaction $\left.=0.031 ; \mathrm{SE}^{2}=0.0001\right)$} \\
\hline Steer & 0.0002 & 0.0005 & 0.0007 & 0.415 & & \\
\hline Heifers & 0.0008 & 0.0009 & 0.0004 & 0.035 & 0.102 & 0.0466 \\
\hline Prob $^{1}$ & 0.047 & 0.117 & 0.266 & & & \\
\hline \multicolumn{7}{|c|}{$\mathrm{C} 24: 1$ cis $15 \mathrm{n}-9\left(P\right.$ interaction $\left.=0.0070 ; \mathrm{SE}^{2}=0.0004\right)$} \\
\hline Steer & 0.007 & 0.010 & 0.010 & 0.005 & 0.0017 & 0.360 \\
\hline Heifers & 0.010 & 0.011 & 0.008 & 0.139 & & \\
\hline Prob $^{1}$ & 0.035 & 0.306 & 0.083 & & & \\
\hline \multicolumn{7}{|c|}{$\Delta^{9}$ desaturase $\mathrm{C} 16\left(P\right.$ interaction $\left.=0.0248 ; \mathrm{SE}^{2}=0.0001\right)$} \\
\hline Steer & 11.68 & 11.31 & 12.70 & 0.873 & & \\
\hline Heifers & 13.33 & 11.53 & 10.97 & 0.032 & 0.0228 & 0.863 \\
\hline Prob $^{1}$ & 0.134 & 0.830 & 0.109 & & & \\
\hline
\end{tabular}

${ }^{1} \mathrm{R}$ Lin: Linear regression. $\mathrm{R}$ Quad: quadratic regression; ${ }^{2} \mathrm{SE}$ : Standard error; $\mathrm{P}^{3}$ : Probability.

${ }^{4} Y=6.39-0.32 X\left(R^{2}=0.29\right) ;{ }^{5} Y=1.68-0.062 X\left(R^{2}=0.36\right) ;{ }^{6} Y=0.0004+0.0005 X-0.0001 X\left(R^{2}=0.45\right) ;{ }^{7} Y=0.0060+$ $0.0008 X\left(R^{2}=0.54\right) ;{ }^{8} Y=13.67-0.56 X\left(R^{2}=0.47\right)$. 
ชิ ๆ

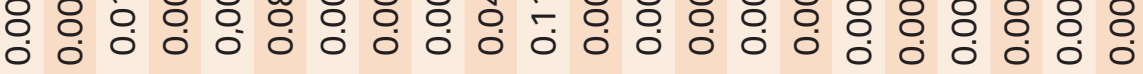

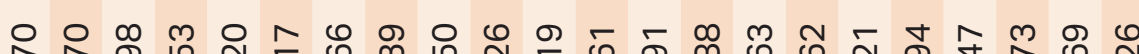

○ $\stackrel{\Phi}{\stackrel{\Phi}{ \pm}}$

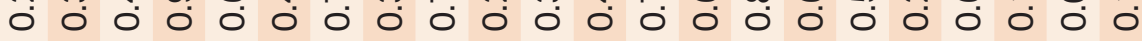

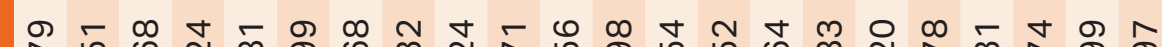

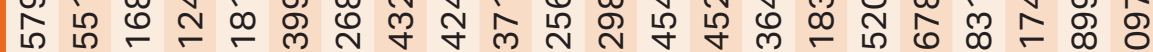

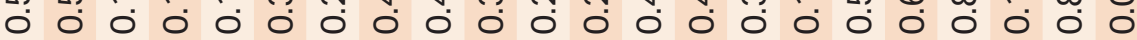

ஜ

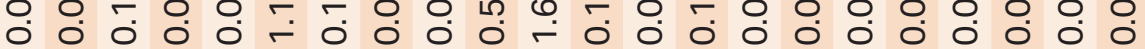

m 0
0

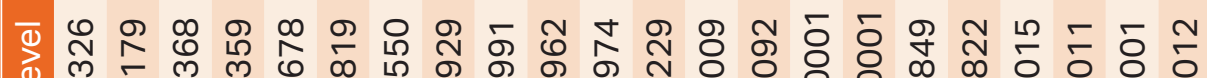

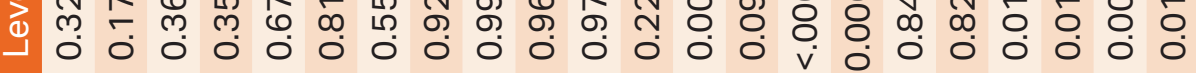

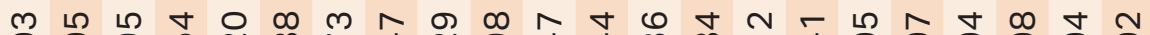

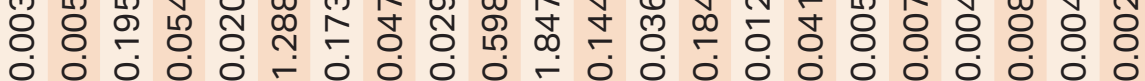

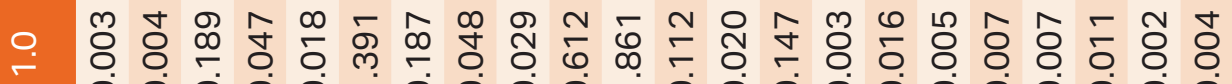

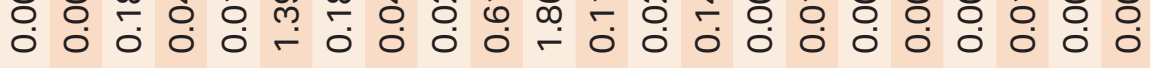


The factors oil level and sexual condition had no interaction ( $P>0.05$ ) for sums, ratios, and quality indexes of fatty acids (Table 5.). A significant interaction was only found for the activity of $\Delta^{9}$ desaturase $\mathrm{C} 16(\mathrm{P}=$ 0.024) (Table 3.); although no effect $(P>0.05)$ was observed for sexual condition, the activity of this enzyme linearly decreased in heifers $(\mathrm{P}<0.05)$. Regarding the classification of fatty acids present in $L M$, a linear increase $(P<$ 0.05 ) was observed for PUFA and $n-3$ with the addition of increasing linseed oil levels into the cattle finishing diets, but not for the other classes (Table 5.). Such increasing levels reduced the $n-6: n-3$ ratio $(P<0.05)$ (Table 5.), with a linear decrease of approximately $50 \%$ when the linseed oil level was raised from 1 to $5.2 \%$. The quality indices of fatty acids in meat were not affected $(P>0.05)$ by the increase in dietary linseed oil levels (Table 5.). Neither were the sums, relationships, and quality of fatty acids in LM (Table 5.) affected by the sexual condition ( $P>0.05)$. Moreover, the activities of $\Delta^{9}$ desaturase $\mathrm{C} 18$ and elongase in LM were not affected $(P>0.05)$ by linseed oil levels or sexual condition (Table 5.).

Increases in linseed oil levels in cattle finishing diets did not cause marked changes in their nutritional values, with an increase in total digestible nutrients of only $6 \%$ from the lowest to the highest oil levels. Thus, no difference in ADG would be expected for animals fed different levels of linseed oil, which indeed did not occur. This result was also reported by Jerónimo et al. (2012), who added vegetable oil to the diet of lambs, and by Fiorentini et al. (2012), who evaluated the use of oil in high-concentrate diets for crossbred heifers. In these studies, energy concentration in diets was low compared to ours.
Nevertheless, ADG found in this study is low and can be explained because animals enter the feedlot with high BW and have a satisfactory feeding condition. The animals were kept on good quality pasture and received $4.0 \mathrm{~kg} / \mathrm{animal}$ per day, which practically suppressed the occurrence of compensatory gain. Additionally, the animals were submitted to a prolonged feedlot period (96-138 d), and their carcasses contained high fat contents. According to Freetly, Kuehn, Thallman and Snelling (2020), ADG is determined genetically and can be altered by nutritional and hormonal factors. Therefore, in this study, the nutritional status of animals before entering the feedlot may have affected their performance, decreasing weight gain rates in the fattening stage.

In contrast, DMI linearly decreased with increasing linseed oil levels because of higher energy: satiety ratios. Consequently, ether extract intake increased with linseed oil levels. It is worth remembering that ruminants have two satiety mechanisms, one physical and the other chemical; the latter is related to the food type consumed to meet animal nutritional demands (Nikkhah, 2011). The inclusion of $5.2 \%$ linseed oil in diets reduced by $8.5 \%$ feed intake compared to the inclusion of $1.0 \%$, improving feed efficiency by about $30 \%$. However, another study showed no change in feed intake or feed efficiency with the inclusion of increasing levels of soybean oil (Fiorentini et al., 2012). In addition to the potential benefits of reduced DMl for cattle production profitability, more efficient animals produce less waste and, therefore, less environmental impact. 


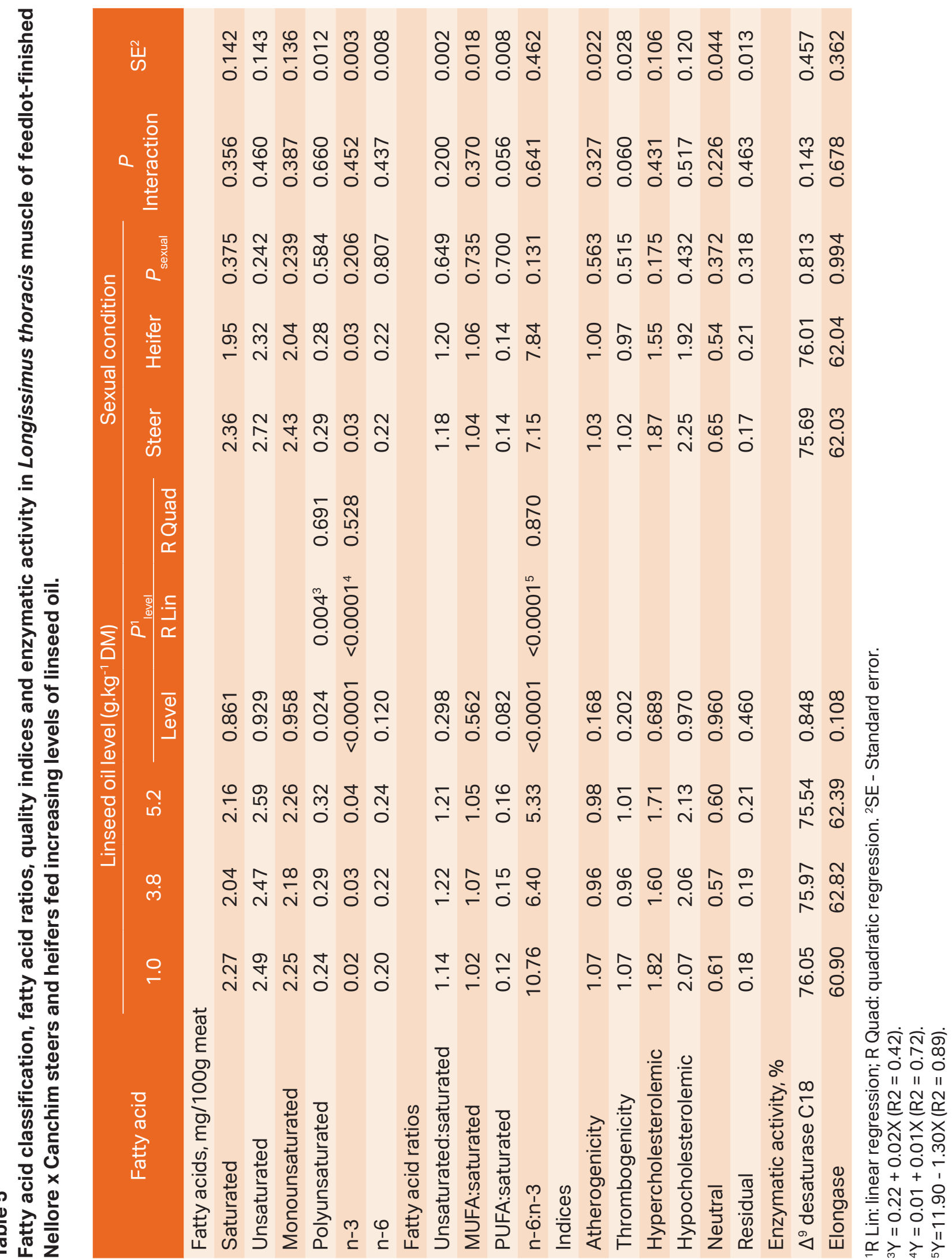


In terms of performance, steers and heifers had similar results. However, steers had higher carcass weight, while heifers had greater fat thickness. This is because females reach mature weight sooner than males and start depositing fat earlier, whereas males have increased muscle deposition (Doyle et al., 2021). Blanco et al. (2020) evaluated steers and heifers and found no difference in weight gain or fat thickness between sexes, probably because animals were purebred Canchim, which is characterized by low-fat deposition. In the present study, males were castrated only at 15 months of age, which allowed the action of male hormones on muscle development. It is noteworthy that initial animal weight was used as a covariate; therefore, some expected differences, such as in final weight and carcass yield, were not observed. Thus, animal weight at the beginning of the feedlot period can be used as a parameter to reach the ideal slaughter weight.

The chemical (moisture, ether extract, and protein) and physicochemical (color, $\mathrm{pH}$, WHC, and cooking losses) characteristics of meat were not influenced by linseed oil levels or sexual condition. This may have been due to similarities in metabolism between heifers and steers. Likewise, Blanco et al. (2020) evaluated heifers and steers finished in the feedlot and did not find differences in meat characteristics. Furthermore, adding vegetable oils to the finishing diet of cattle does not improve meat tenderness, as already demonstrated by Oliveira et al. (2012) and González, Moreno, Bispo, Dugan and Franco (2014); just as by our results. Differences in shear force of steer and heifer meat were observed between $1.0 \%$ and $3.8 \%$ linseed oil in diets, but none at $5.2 \%$. This may occur because increasing dietary linseed oil levels can affect the activity of calciumdependent enzymes, such as calpain and calpastatin. According to Marenčić, Ivanković, Kozačinski, Popović and Cvrtila (2018), factors associated with sex differences and meat tenderness include circulating hormone levels in the body, temperament and reactivity to pre-slaughter handling, as well as calpastatin activity and its association with postmortem tenderization. In this respect, Coutinho et al. (2017) reported greater calpastatin activity in LM of heifers when compared to steers. Although shear force decreased in heifers and was maintained in steers, energy sources used in this study were insufficient to produce a tender ribeye cut, as average shear force remained above $5.85 \mathrm{~kg}$ (Mayer et al., 2017).

Increasing linseed oil levels in animal diets proved to improve meat lipid composition. Although there was no reduction in saturated fatty acids, such as myristic and palmitic acids, PUFA increased, which, in turn, has a positive influence on human health. These increases were due to higher concentrations of CLA, $\alpha$-linolenic acid, $y$-linolenic acid, and EPA, with the former being considered essential for humans. This fatty acid plays an important role in reducing cardiovascular disease risks and cholesterol levels, besides its potential to fight obesity (Niewiadomska et al., 2020). Increases in this fatty acid in meat were exclusively due to biohydrogenation of unsaturated fatty acids in the rumen, as the activity of $\Delta^{9}$ desaturase enzymes in LM was not influenced by increasing levels of dietary oil. Adding vegetable oils to cattle diets generally raises CLA contents (Oliveira et al., 2012) even if lowPUFA oils are used (Gema \& Gaspar, 2012).

In our study, $\alpha$-linolenic concentration was higher when animals were fed diets with 
$5.2 \%$ linseed oil. According to Gema and Gaspar (2012), linseed oil favors an increase in proportions of PUFA and CLA in beef. The $\alpha$-linolenic is also important for the biosynthesis of other very-long-chain fatty acids (VLCFAs) such as arachidonic acid (Zunin, Boggia, Turrini, \& Leardi, 2015). Therefore, higher $\alpha$-linolenic acid concentrations may have also favored the amount of EPA in this study. In addition, the use of linseed oil resulted in an increase in $\mathrm{Y}$-linolenic acid, as reported by Oliveira et al. (2012), and Albertí et al. (2014). Santos, Oliveira, Moreli and BeniteRibeiro (2018) mentioned that fatty acids such as $y$-linolenic acid, arachidonic acid, and EPA play a key role in the formation of eicosanoids such as prostaglandins.

Contents of the VLCFAs eicosadienoic acid, eicosatrienoic acid, and DTA decreased with increasing linseed oil levels. Such reductions are contradictory to our hypothesis, in which increasing linseed oil levels would promote an increase in most long-chain PUFA levels. This is because the formation of these fatty acids is catalyzed by elongases and desaturases from the precursors $\alpha$-linolenic acid and $\gamma$-linolenic acid (Vagner \& Santigosa, 2011). Similar results have been reported by Fiorentini et al. (2012), who found a reduction in DTA content with increasing soybean oil levels in cattle diets and attributed it to a potential decrease in the activity of desaturases, especially $\Delta^{5}$ and $\Delta^{6}$. Calvo et al. (2019) suggested that reductions in the activity of desaturases in muscle tissue are due to the presence of long-chain PUFA in the diet offered.

In this sense, we believe that interactions between arachidonic acid, DHA, and nervonic acid are also related to $\Delta 6$ desaturase activity. This is because heifers had higher concentrations of these fatty acids than did steers, only for animals fed the diet with $1 \%$ linseed oil. Therefore, sexual condition and higher dietary oil levels may have decreased this enzyme activity, thereby reducing significantly the concentrations of some VLCFAs. These results are supported by Choque, Catheline, Rioux and Legrand (2014), who showed that high concentrations of linseed oil inhibit the activity of $\Delta 6$ desaturase.

Higher n-3 levels and improved n-6:n-3 ratio are related to individual increases in $\alpha$-linolenic acid and EPA, which are used to compose the sum of $n-3$ fatty acids. If the oil added to diets was rich in n-3 fatty acids, the $n-6: n-3$ ratio is expected to decrease effectively, as demonstrated by Oliveira et al. (2012) and González et al. (2014) for linseed oil. Reductions in n-6:n-3 ratios are positively related to healthier meat cuts for human consumption. According to Zunin et al. (2015), n-6 and n-3 fatty acids, such as linoleic and linolenic acids, are required for cell membrane integrity maintenance, brain functioning, nerve impulse transmissions, atmospheric oxygen transfer to blood plasma, hemoglobin synthesis, and cell division processes. These authors suggested ideal $n-6: n-3$ ratios within the range of $4: 1$ to $5: 1$ for the whole diet. Increases in linseed oil levels in finishing diets for steers and heifers improved beef quality, reducing the $n-6: n-3$ ratio by 1.3 points per percentage of oil level increased, according to the equation obtained for this variable $(Y=$ $11.90-1.30 \mathrm{x}$ ). Although beef is only of the food sources in the Western diet, including 5.2\% linseed oil in cattle diets allowed the ratio of $n-6: n-3$ to be within the range recommended by Zunin et al. (2015). 


\section{Conclusion}

Increasing levels of linseed oil are recommended for diets of feedlot-finished crossbred steers and heifers because they increase feed efficiency, reducing DMl at a rate of $200 \mathrm{~g}$ per unit increase in oil. Furthermore, beef quality is significantly improved by increasing PUFA and $\mathrm{n}-3$ fatty acids, in addition to reducing the $n-6: n-3$ ratio by 1.3 points per percentage point increase of linseed oil in the finishing diets of both steers and heifers.

\section{Acknowledgments}

We thank the São Paulo Research Foundation (FAPESP) and A Nutreco Company for funding this research.

\section{References}

Abuelfatah, K., Zuki, A. B., Goh, Y. M., Sazili, A. Q., \& Abubakr, A. (2016). Effects of feeding whole linseed on ruminal fatty acid composition and microbial population in goats. Animal Nutrition, 2(4), 323-328. doi: 10.1016/j.aninu.2016.10.004

Abularach, M. L., Rocha, C. E., \& Felício, P. E. (1998). Características de qualidade do contrafilé (m. L. dorsi) de touros jovens da raça Nelore. Ciência e Tecnologia dos Alimentos, 18(1), 205-210. doi: 10.1590/ S0101-20611998000200012

Albertí, P. M., Beriain, J., Ripoll, G., Sarriés, V., Panea, B., Mendizabal, J. A.,... Sañudo, C. (2014). Effect of including linseed in a concentrate fed to young bulls on intramuscular fatty acids and beef color. Meat Science, 96(3), 1258-1265. doi: 10.1016/j.meatsci.2013.11.009
Association of Official Analytical Chemists (1995). Official methods of analysis (16nd ed. rev.). Washington, DC: AOAC.

Association of Official Analytical Chemists (2005). Official methods of analysis (18nd ed. rev.). Washington, DC: AOAC.

Bessa, R. J. B., Lourenço, M., Portugal, P. V., \& Santos-Silva, J. (2008). Effects of previous diet and duration of soybean oil supplementation on light lambs carcass composition, meat quality and fatty acid composition. Meat Science, 80(1), 11001105. doi: 10.1016/j.meatsci.2008.05.001

Blanco, M., Ripoll, G., Delavaud, C., \& Casasús, I. (2020). Performance, carcass and meat quality of young bulls, steers and heifers slaughtered at common body weight. Livestock Science, 240(1), 104156. doi: 10.1016/j.livsci.2020.104156

Bligh, E. G., \& Dyer, W. J. (1959). A rapid method of total lipid extraction and purification. Canadian Journal of Biochemistry Physiology, 37(1), 911-917. doi: 10.1139/ 059-099

Calvo, J. H., González-Calvo, L., Dervishi, E., Blanco, M., Iguácel, L. P., Sarto, P.,... Joy, M. (2019). A functional variant in the stearoylCoA desaturase (SCD) gene promoter affects gene expression in ovine muscle, Livestock Science, 219(1), 62-70. doi: 10.1016/j.livsci.2018.11.015

Choque, B., Catheline, D., Rioux, V., \& Legrand, P. (2014). Linoleic acid: between doubts and certainties. Biochimie, 96(1), 14-21. doi: 10.1016/j.biochi.2013.07.012

Coutinho, M. A. da S., Ramos, P. M., Silva, A. da L., Martello, L. S., Pereira, A. S. C., \& Delgado, E. F. (2017). Divergent temperaments are associated with beef tenderness and the 
inhibitory activity of calpastatin. Meat Science, 134(1), 61-67. doi: 10.1016/j. meatsci.2017.06.017

Cupersmid, L., Fraga, A. P. R., Abreu, E. S. de, \& Pereira, I. R. O. (2012). Linhaça: composição química e efeitos biológicos. e-Scientia, 5(2), 33-40. Available in: www. unibh.br/revistas/escientia/.

Doyle, J. L., Purfield, D. C., Moore, T., Carthy, T. R., Walsh, S. W., Veerkamp, R. F.,... Berry, D. P. (2021). Identification of genomic regions that exhibit sexual dimorphism for size and muscularity in cattle. Journal of Animal Science, 99(5). doi: 10.1093/jas/ skab070

Fiorentini, G., Berchielli, T. T., Santana, M. C. A., Dian, P. H. M., Reis, R. A., Sampaio, A. A. M., \& Biehl, M. V. (2012). Qualitative characteristics of meat from confined crossbred heifers fed with lipid sources. Scientia Agricola, 69(5), 336-344. doi: 10.1590/S0103-90162012000500008

Freetly, H. C., Kuehn, L. A., Thallman, R. M., \& Snelling, W. M. (2020). Heritability and genetic correlations of feed intake, body weight gain, residual gain, and residual feed intake of beef cattle as heifers and cows. Journal of Animal Science, 98(1), 1-6. doi: 10.1093/jas/skz394

Gema, N., \& Gaspar, R. (2012). Modification of fatty acid composition in meat through diet: effect on lipid peroxidation and relationship to nutritional quality - a review. Lipid Peroxidation, 12(1), 239-258. doi: $10.5772 / 51114$

González, L., Moreno, T., Bispo, E., Dugan, M. E. R., \& Franco, D. (2014). Effect of supplementing different oils: Linseed, sunflower and soybean, on animal performance, carcass characteristics, meat quality and fatty acid profile of veal from "Rubia Gallega" calves. Meat Science, 96(2), 829-836. doi: 10.1016/j. meatsci.2013.09.027

Hamm, R. (1986). Functional properties of the myofibrillar system and their measurement. In P. J. Bechtel (Ed.), Muscle as food (pp. 135-199). Orlando (USA): Academic Press.

Houben, J. H., Van Dijk, A., Eikelenboom, G., \& Hoving-Bolink, A. G. (2000). Effect of dietary vitamin $\mathrm{E}$ supplementation, fat level and packaging on color stability and lipid oxidation in minced meat. Meat Science, 55(1), 331-336. doi: 10.1016/ s0309-1740(99)00161-8

ISO 5509 (1978) - Animal and vegetable fats and oils - Preparation of methyl esters of fatty acids. Available in: https://www.iso. org/standard/11559.html.

Jerónimo, E., Alfaia, C. M., Alves, S. P., Dentinho, M. T., Prates, J. A., Vasta, V.,... Bessa, R. J. (2012). Effect of dietary grape seed extract and Cistus ladanifer $L$. in combination with vegetable oil supplementation on lamb meat quality. Meat Science, 92(4), 841847. doi: 10.1016/j.meatsci.2012.07.0 11

Kalupahana, N. S., Claycombe, K. J., \& MoustaidMoussa, N. (2011). (n-3) Fatty acids alleviate adipose tissue inflammation and insulin resistance: mechanistic insights. Advances in Nutrition, 2(4), 304-316. doi: 10.3945/an.111.000505

Malau-Aduli, A. E. O., Siebert, B. D., Bottema, C. D. K., \& Pitchford, W. S. (1998). Breed comparison of muscle phospholipids in Jersey and Limousin cattle. Journal of Animal Science, 76(3), 766-773. doi: 10. 2527/1998.763766x 
Marenčić, D., Ivanković, A., Kozačinski, L., Popović, M., \& i Cvrtila, Ž. (2018). The effect of sex and age at slaughter on the physicochemical properties of baby-beef meat. Veterinarski Arhiv, 88(1), 101-110. doi: 10.24099/vet.arhiv.160720

Mayer, A. R., Rodrigues, L. S., Alves, D. C., Fo., Cattelam, J., Callegaro, A. M., Argenta, F. M.,... Pacheco, P. S. (2017). Carcass characteristics and meat quality from steers fed with different energetic sources. Revista Espacios, 38(37), 8-20. Available in: https://www.revistaespacios. com/a17v38n37/17383708.html.

Nassu, R.T., Dugan, M., He, M., McAllister, T., Aalhus, J., Aldai, N., \& Kramer, J. (2011). The effects of feeding flaxseed to beef cows given forage-based diets on fatty acids of longissimus thoracis muscle and backfat. Meat Science, 89(4), 469-77. doi: 10.1016/j.meatsci.2011.05.016

Niewiadomska, K., Kosicka-Gębska, M., Gębski, J., Gutkowska, K., JeżewskaZychowicz, M., \& Sułek, M. (2020). Game meat consumption-conscious choice or just a game?. Foods, 9(10), 1357-1370. doi: $10.3390 /$ foods9101357

Nikkhah, A. (2011). Bioscience of ruminant intake evolution: feeding time models. Scientific Research, 2(4), 271-274. doi: 10.4236/abb.2011.24039

Oliveira, E. A., Sampaio, A. A. M., Henrique, W., Pivaro, T. M., Rosa, B. L., Fernandes, A. R. M., \& Andrade, A. T. (2012). Quality traits and lipid composition of meat from Nellore young bulls fed with different oils either protected or unprotected from rumen degradation. Meat Science, 90(1), 28-35. doi: 10.1016/j.meatsci.2011.05.024
Oliveira, E. A., Sampaio, A. A. M., Rosa, B. L., Henrique, W., Pivaro, T. M., Carvalho, V. G.,... Duckett, S. K. (2017). Quality characteristics of meat from triceps brachii muscle from steers and heifers finished on high-concentrate diets containing increasing concentrations of linseed oil. Animal Production Science, 58(11), 2117-2125. doi: 10.1071/an16147

Saldanha, T., Mazalli, M. R., \& Bragagnolo, N. (2004). Avaliação comparativa entre dois métodos para determinação do colesterol em carnes e leite. Ciência Tecnologia de Alimentos, 24(1), 109-113. doi: 10. 1590/ S0101-20612004000100020

Santos, J. M. dos, Oliveira, D. S. de, Moreli, M. L., \& Benite-Ribeiro, S. A. (2018). The role of mitochondrial DNA damage at skeletal muscle oxidative stress on the development of type 2 diabetes. Molecular and Cellular Biochemistry, 449(1-2), 251-255. doi: 10.1007/s11010018-3361-5

Ulbricht, T. L. V., \& Southgate, D. A. T. (1991). Coronary heart disease: seven dietary factors. Lancet, 338(1), 985-992. doi: 10.1016/0140-6736(91)91846-m

Vagner, M., \& Santigosa, E. (2011). Characterization and modulation of gene expression and enzymatic activity of delta-6 desaturase in teleosts: a review. Aquaculture, 315(1), 131-143. doi: 10.10 16/j.aquaculture.2010.11.031

Vahmani, P., Ponnampalam, E. N., Kraft, J., Mapiye, C., Bermingham, E. N., Watkins, P. J.,... Dugan, M. E. R. (2020). Bioactivity and health effects of ruminant meat lipids. Invited review. Meat Science, 165(1), 108114. doi: 10.1016/j.meatsci. 2020.108114 
Vargas-Bello-Pérez, E., \& Larraín, R. E. (2017). Impacts of fat from ruminants' meat on cardiovascular health and possible strategies to alter its lipid composition. Journal of the Science of Food and Agriculture, 97(7), 1969-1978. doi: 10.10 02/jsfa.8168

Wheeler, T. L., Vote, D., Leheska, J. M., Shackelford, S. D., Wulf, D. M., Gwartney, B. L., \& Koohmaraie, M. (2002). The efficacy of three objective systems for identifying beef cuts that can be guaranteed tender. Journal of Animal Science, 80(1), 33153327. doi: $10.2527 / 2002.80123315 x$
Wood, J. D. (2017). Lawrie's meat science. In Fidel Toldrá (Ed.), Composition and nutritional value of meat (pp. 635-659). Cambridge, UK: Appleton.

Zunin, P., Boggia, R., Turrini, F., \& Leardi, R. (2015). Total and "free" lipids in commercial infant formulas: Fatty acid composition and their stability to oxidation. Food Chemistry, 173(1), 332-338. doi: 10.1016/j.foodchem. 2014.10.014 
